\title{
Being Homeless and Becoming Housed: The Interplay of Fateful Moments and Social Support in Neo-liberal Context
}

JASON WEBB

York University, Canada

AMBER GAZSO

York University, Canada

ABSTRACT This paper presents a qualitative analysis of stories of adults who transitioned from being absolutely homeless to becoming housed. Participants' stories are particularly salient for what they reveal about this transition in the midst of other challenges including substance use, criminalization, and violence, and within a neoliberal social policy context. Through strategies of narrative analysis, two interconnected processes of becoming housed are discovered: (a) experiencing fateful moments; and (b) perceiving and creating social supports. The main conclusion is that fateful moments in individuals' lives intersect with the push and pull of instrumental and expressive supports from family, community, and the state to culminate in an exit from absolute homelessness. The implications of these findings for understanding and responding to homelessness are also discussed.

KEYWORDS homelessness; becoming housed; narrative analysis; fateful moment; social supports

In this paper, we present findings from a qualitative analysis of interviews with previously homeless adults to explore their stories of becoming housed in Toronto, Ontario in the midst of multiple personal and structural challenges. Beyond lack of shelter, these included drug use, violence on the streets, and weakened state provisions for income security. Through stories, we see the interplay between fateful moments and social supports. Specifically, becoming housed occurred when moments of epiphany in individuals' lives intersected with the push and pull of instrumental and expressive supports from family, community, and the state. This main finding permits us to critically engage with some assumptions of the current neo- 
liberal social policy context (McKeen \& Porter, 2003; Rice \& Prince, 2013), such as the ideas that individuals are self-sufficient, personally motivated, and reject social or public intervention in their lives in their conformity to a strong market ethos (Harvey, 2007; Howard, 2007). For example, we note that individuals' experiences of fateful moments can be seen to invoke feelings of self-sufficiency and personal responsibility necessary to their becoming housed. However, we argue that because these fateful moments intersect with socially supportive relations, this disturbs the assumption that the adoption of these and other neo-liberal imperatives are the sole reasons for leaving the street. Our research therefore offers an opportunity to theorize the difficulties inherent in responding to homelessness and implementing a housing strategy in the neo-liberal era of the late welfare state.

\section{The Social Policy Context}

In Canada, an estimated 35,000 people are absolutely homeless, living "rough" on the street or in shelters, and another estimated 50,000 people are precariously housed (e.g., couch surfing at family and friends' homes) (Gaetz, 2010; Gaetz, Gulliver \& Richter, 2014). Although there is considerable diversity among persons who are homeless, Aboriginal peoples and queer youth are disproportionately represented (Belanger, Awosoga \& Head, 2013; City of Toronto, 2013). In some cities and regions such as the Greater Toronto Area and Peel Region, the number of persons absolutely homeless continues to grow (City of Toronto, 2013; Daiski, Halifax, Mitchell \& Lyn, 2012). According to the 2013 Street Needs Assessment survey, over 5,000 homeless people in Toronto (population approximately 2.9 million) spent the evening of April 17, 2013, outdoors or in city-administered shelters or treatment or correctional facilities (City of Toronto, 2013, p. 13).

Homelessness in Canadian cities is attributed to social and structural change (Gaetz, Donaldson, Richter \& Gulliver, 2013). A labour market characterized by an increase in employment that is part-time, contractual, seasonal and low-waged has contributed to financial insecurity or poverty in many households (Lewchuk, 2013; Shier, Jones \& Graham, 2010). While the wealthiest in Canada have become wealthier, persons of lower and middle incomes have experienced stagnating incomes or greater income insecurity (Organization for Economic Co-operation \& Development, 2008; Broadbent Institute, 2014), and the withdrawal of welfare state protection through neoliberal restructuring.

As a policy framework, neo-liberalism favours individual freedom of choice, responsibility, self-sufficiency, and correspondingly, reducing the role of the state in people's lives and encouraging market competition 
(Brodie, 2007; Larner, 2000). ${ }^{1}$ Problems of income insecurity are attributed to individual failings at being risk taking, market citizens (i.e., employed), rather than to political, economic, and structural conditions (Dolson, 2015; Harvey, 2007; Larner, 2000; McKeen \& Porter, 2003). Scholars generally agree that the neo-liberal policy framework in Canada has meant a decline in the social safety net (Rice \& Prince, 2013), and, specifically, the restructuring of policies and programs that could prevent homelessness or support homeless people.

The post-1960s deinstitutionalization movement, for example, removed persons with mental health problems from institutions out of respect for their rights and autonomy, but placed them in communities where services that would provide safe, adequate care and affordable housing were underfunded (Armstrong \& Armstrong, 2010; Niles, 2013; Snow \& Anderson, 1993). Second, eligibility for social assistance has tightened and become conditional on employability efforts post-1990. While receipt of social assistance was always to be "a last resort" and never meant to replace income from paid work, the introduction of stricter welfare-to-work program requirements has represented a distinct shift away from social citizenship and entrenchment of market citizenship as a basis to claim income support (Gazso, 2012). Third, in the 2000s, neo-liberalism has become linked with criminalization of the homeless in the name of public safety (Gaetz, 2013). When the provincial governments of Ontario and British Columbian enacted the Safe Streets Act, in 1999 and 2004 respectively, police officers were given the power and authority to ticket street-involved homeless people for panhandling and squeegeeing in public (Gaetz, 2013; O’Grady, Gaetz \& Buccieri, 2013).

Finally, the lack of a long-term, affordable housing strategy has long been cited as a major explanation of homelessness. Between 1989 and 2009, the federal government's investment in affordable housing declined $40 \%$ in relation to total GDP expenditures (Lewchuk, 2013). In 1996, the responsibility for provisions of affordable housing was devolved to the provinces (Hulchanski, 2009). Between 1991 and 2006, household demand for affordable housing in Ontario increased by 200,000 , with 627,535 households in need in 2006 (Ontario Ministry of Municipal Affairs \& Housing, 2014). In the city of Toronto, the average waiting time for affordable housing is 8.4 years (Monsebraaten, 2016). The Ontario provincial government has yet to release its own strategy to deliver affordable housing.

\footnotetext{
${ }^{1}$ We acknowledge that neo-liberalism as a coherent project is contested in Canada and elsewhere (Larner, 2000; Peck \& Tickel, 2002).
} 


\section{Transitions in Homelessness: The Current Literature}

The current literature on homelessness is heavily concentrated on reasons for becoming homeless and the experience of homelessness. Becoming homeless can be explained through the metaphor of a pathway (Chamberlain \& Johnson, 2013; Mallet, Rosenthal \& Keys, 2005). For example, unemployment, poverty, housing crisis, family break-down, mental and physical health challenges, substance use, and problematic contact with the child welfare system have been found to lead to homelessness (Belcher \& DeForge, 2012; Coates \& McKenzie-Mohr, 2010; Chamberlain \& Johnson, 2013; Gaetz, 2013; Karabanow, 2008; Thompson, Bender, Windsor, Cook \& Williams, 2010). Pathways into homelessness can also differ by gender, race/ethnicity, and Indigeneity (Anderson \& Collins, 2014; Tutty, Ogden, Giurgiu \& Weaver-Dunlop, 2013. p. 1505). The causes of the overrepresentation of Indigenous peoples among Canada's homeless are argued to additionally include the nation's history of colonial policies and practices (e.g., residential schools) and ongoing discrimination (Anderson \& Collins, 2014).

The everyday life experience of being homeless is understood to be compounded by many of the same factors that led to homelessness. Homeless women have been found to experience higher levels of mental health problems than homeless men (Nemiroff, Aubry \& Klodawsky, 2010). Substance use has been studied as an effect, not just a cause of homelessness (Duneier, 1999; Grinman et al., 2010). Research into work-family dimensions of homelessness has been a particularly important contribution to the literature. Scholars find that people who are homeless engage in a variety of subsistence activities, including paid employment (Karabanow, Hughes, Ticknor \& Kidd, 2010; Shier, Jones \& Graham, 2010; Persaud, McIntyre \& Milaney, 2010). And whereas research of the past assumed that the homeless experience was one of social isolation, more recent research reveals that diverse interpersonal relationships among homeless people develop in response to their circumstances (Dordick, 1997; Irwin, LaGory, Ritchey \& Fitzpatrick, 2008; Karabanow, 2008; Rokach, 2004, 2005; Stablein, 2011; Sterk-Elifson \& Elifson, 1992; Toro \& Oko-Riebau, 2015; Toro, Tulloch \& Ouellette, 2008). For example, Bourgois and Schonberg's (2009) ethnography on homeless intravenous substance users in California revealed that they develop a moral economy of mutual support to endure the criminalization of their substance use engendered by the United States' War on Drugs.

Questions around how homeless individuals becoming housed have perhaps been better answered with regard to the experiences of youth. Qualitative studies have found that homeless youth are more likely to exit the street if they are personally motivated, have supportive relationships with family and community service providers, and access affordable housing and income support (Karabanow, 2008; Wilks, Hiscock, Joseph, Lemin \& 
Stafford, 2008). For youth who have experienced trauma before and during homelessness, access to services like therapeutic counseling is important for transitioning off Canadian streets (Coates \& McKenzie-Mohor, 2010).

Studies that have focused on adults' exits from homelessness all point to access to affordable housing as a primary reason, but are mixed in their findings on the importance of other factors. Klodawsky, Aubry, Nemiroff, Bonetta and Willis's (2007) mixed method and longitudinal study of adult homelessness in Ottawa led them to conclude that economic factors, interpersonal supports and conflicts, health problems including substance use, and access to housing and community services can both impede and facilitate exits. Focusing on homeless Canadian women, Nemiroff, Aubry and Klodawsky's (2010) quantitative study showed that exits were more likely for those with dependent children, which they attribute to women's personal motivation to be caregivers and their access to subsidized housing. For persons with a history of mental illness and housing instability, developing strong relationships with others was crucial to their "gaining stability" and therefore maintaining housing (Forchuk, Ward-Griffin, Csiernik \& Turner, 2006). Zlotnick, Tam and Robertson's (2003) quantitative study based in Alameda County in the United States found mixed support, however, for whether family, friends, and community services facilitate exits from the street. For those with substance use problems, social networks had little impact on leaving the street.

We now turn to our own qualitative research which afforded us an opportunity to consider to what extent several of the above factors mattered to the re-housing of absolutely homeless adults, especially in view of how this transition occurred in the neo-liberal social policy context we described earlier.

\section{Methods}

The narratives we analyze were extracted from a larger qualitative, crosssectional study of which the second author was the principal investigator. This study explored how families create networks of social support to manage low income in the Greater Toronto Area by drawing on informal and formal sources of instrumental and expressive support. ${ }^{2}$ In the larger project, 70 participants aged 16 and older and representing 20 "families by choice" (kin and fictive kin relations) participated in semi-structured interviews with

\footnotetext{
${ }^{2}$ Our research distinguishes between source and type of social support. Whereas informal sources of support include family and friends, formal sources of support included community supports like foodbanks and state supports like social assistance. And whereas instrumental support includes financial or material assistance and physical aid, expressive support includes affection and guidance.
} 
the second author or a research assistant between 2009 and $2010 .^{3}$ The design of this larger study integrated insights from the life course perspective, which understands events over a person's life course (e.g., high school graduation, child birth) to be agentially, structurally, and historically constituted and to further shape specific trajectories (e.g., family or career) and relationships with others (Elder, 1994, 1998). Single-point-in-time, semi-structured interviews with members of each family by choice raised questions about events that prompted participants' creation and use of social support networks, and how types and sources of support changed over time. ${ }^{4}$ Interviews lasted on average an hour and a half and were audio recorded. All 70 transcribed interviews were coded using the qualitative software NVivo, first by common words and ideas, and then for common themes, following grounded theory principles of coding (e.g., open and axial coding) (Strauss \& Corbin, 1998).

In our later reflections on data collection and initial analyses, we were intrigued by the stories that 15 participants shared with the second author. These 15 participants were part of five families by choice. ${ }^{5}$ Some of the experiences of these 15 participants were shared with the entire sample (e.g., the creation of families by choice because of distinct life course events, such as immigration and family conflict) (see, e.g., Gazso \& McDaniel, 2015). Their transitions into and out of absolute homelessness, however, further set these 15 participants apart from the larger sample. The 15 participants included six lone mothers, three common law couples (both partners interviewed), two single men, and one single woman. All lived in subsidized housing at the time of the interview and accessed Ontario Works (social

\footnotetext{
3 The second author completed interviews with 55 of 70 participants; 15 participants were interviewed by a research assistant. Participants were recruited using purposive and snowball sampling at non-profit organizations targeting low-income families. The initial participant had to be over the age of 16, experiencing low income and parenting a child; the participants who were subsequently interviewed made up their family as the initial participant defined it. Participants ranged in age from 18 to 84 and "families by choice" ranged in size from two to seven people including kin and fictive kin. That is, families by choice included biological or marital relations (kin) and people unrelated by blood, marriage, or adoption but perceived as family (fictive kin).

${ }^{4} \mathrm{We}$ acknowledge the limitations of single-point-in-time interviews, such as those articulated by Briggs (1986). As well, we recognize that a life course perspective may be perceived as most rigorously applied and theorized through longitudinal research in general, and through ethnographic methods in particular. In this paper, our approach follows research in sociology that draws on insights from a life course perspective to interpret cross-sectional quantitative (Prus, 2004), mixed methods (Cooke \& Gazso, 2007; McDonald, 2011), and qualitative data (Allen \& Picket, 1987; McDaniel, Gazso \& Duncan, 2016). Such cross-sectional research is thought to reflect the life course perspective in the design of (open or close-ended) questions written to enable participants to provide an overview of life course events and transitions retrospectively, in the present, and prospectively. This orientation was embedded in interview questions, which were designed by the second author in consultation with other, collaborating researchers in the original, larger study.

${ }^{5}$ Given our use of purposive and convenience sampling, note that not all members of these five families by choice experienced homelessness. Hence, ours is not a paper about homeless families.
} 
assistance) for income. They ranged in age from 21-54 years. All were parents but only 10 had children in their care; the remaining participants' children were in the care of others or the child welfare system. Eleven of the participants were in recovery from drug or alcohol addiction. Each told stories of becoming housed in the midst of variable experiences of substance use, criminalization, and violence. We were compelled to try to understand their stories and found we could do so through narrative analysis.

Narrative analysis celebrates the diversity of individual experience and is particularly adept at revealing lives considered marginal (Bischoping \& Gazso, 2016; Benjamin, 1968; Jackson, 2002). Through the act of storytelling, participants are understood to develop a sense of agency, articulate purpose, and create their belonging in their social context (Jackson, 2002); a narrative retains "traces of the storyteller" and may also bestow wisdom onto others (Benjamin, 1968, p. 367). In narrative analysis, the story produced or collected is understood to be co-constituted by the interviewer and participant (see also Briggs, 1986; Mishler, 1991). The analyst particularly focuses on participants' recounting of their life experiences over time, with emphasis on the meanings therein. As well, as previous research has established, a small sample $(<20)$ is not unusual in analysis attuned to a rich understanding of unique cases (Crouch \& McKenzie, 2006), the plot of each narrative and the narrator's evaluation of it (Ahmed, 2013), or how transitions and turning points shape a life course in opposition to traditional work-family trajectories (Mykelbust \& Solvang, 2006).

Our analysis strategies were informed by those used in the study of narratives from the life course perspective. We explored participants' narratives for reference to the events or transitions that precipitated or were linked to their homelessness, as well as perhaps their addiction and criminalization. We did so under the assumption that some participants would contextualize their stories of becoming housed, the recent past, by "back stories" about becoming homeless or life on the street. We also endeavored to discover the turning points or fateful moments that prompted participants to dramatically alter the course of their lives, understanding these as culturally and institutionally contextualized (Berger, 2008; Giddens, 1991; Goodey, 2000; MacKnee \& Mervyn, 2002). We were sensitive to Gasker's (1999) insight that epiphanies are symbolic events in a life course that individuals will define as such. Finally, we analyzed narratives about becoming housed for what they revealed about how participants perceive and make sense of changes in their identities and self (see also Linde, 1993). ${ }^{6}$

Each author re-visited the interview transcripts and coded them according to these interests. We analyzed stories for each participant alone and then

${ }^{6}$ For this strategy, we understood identities to emerge from relations with others (Mead, 1984), including to whom an individual is accountable, and perceived that these relations further result in individuals' creation, reproduction, or revision of their identities (e.g., from child to street youth) (Adams \& Marshall, 1996; Kroger, 2000; Raskin, 2006). 
considered the interviews as an ensemble. Throughout, we compared our coding and re-coded our data to achieve a shared perspective. Upon completion of our analysis, we found we were able to categorize the thoughts, actions, interactions with others (e.g., friends, caseworkers), and changes in self behind leaving the street according to two interconnected processes: experiencing fateful moments; and perceiving and creating social supports.

Although each process describes the stories of all 15 participants, we focus on only the stories of five participants in this paper due to limitations of space. These five participants represented Family 19 in the original project and included Amy and her partner Isaac, and Amy's close friends Elijah, Jennifer and Andrew; the latter two friends are a couple. ${ }^{7}$ When we met them, all were housed, receiving Ontario Works entitlements, recovering from addiction, and identified each other as family. Amy and Isaac shared the raising of their son with Isaac's mother, Isabel. Jennifer, Andrew, and Elijah all had children but these children did not live with them and were either in the care of an ex-partner or grandparents, or had been adopted by others. Amy and Isaac self-reported their race as "mixed" (e.g., Caucasian, Black, Aboriginal), Andrew and Elijah identified as Black, and Jennifer as Métis. Below, we briefly sketch out some highlights of the "back-stories" of members of Family 19. These back-stories begin to suggest the significance of absolutely homeless persons becoming housed given multiple challenges, including the neo-liberal social policy context.

- Amy (age 30) grew up in and out of foster care because of her mother's addiction and never achieved a feeling of security or home. She steadily increased her use of crack cocaine throughout late adolescence and eventually ended up on the street.

- Isaac (age 32) began to use drugs as an adolescent. After his parent's divorce, he had a tumultuous relationship with this father who also experienced addiction; he recalls engaging in substance use with him. Eventually Isaac dropped out of high school and started "running the streets." Following his placement in foster care by child welfare services and his continued drug use, he became homeless.

- Elijah (age 49) witnessed the murder of his father before he immigrated to Canada at age six. He experienced feelings of isolation and inability to conform to the norms of his mother's household during his young childhood and adolescence. His greater attachment to his peers and drug use in young adulthood contributed to his homelessness. As he recalled "slowly over the years the character started to change. So now I started to become a street person. Instead of like a decent guy that dresses up nice. And then I started dressing like a bum..."

- Jennifer (age 36) remembers her life growing up in Manitoba as one of moving back and forth between her mother and grandmother's house. She left her grandmother's home at the age of 15, the first of many entrances

\footnotetext{
${ }^{7}$ The participants' names were changed to ensure anonymity and confidentiality.
} 
onto the street, because her grandmother's boyfriend sexually abused her. In her words, "I didn't really have much of a childhood... I was really young. I think my first drink I had when I was eight, started drinking heavy at 12,13 , left home at 15 . I was like a full-blown alcoholic by then probably."

- Andrew (age 39) dropped out of high school in adolescence. He met his father for the first time at age 17 in hospital when he became severely ill. His homelessness was connected to his gang-related crime, incarceration, addiction, and the subsequent strained relationships he had with his mother and other family members.

\section{Findings}

\section{Experiencing Fateful Moments}

As we have observed, participants' experiences of absolute homelessness were marked by hardships. Beyond absolute poverty, these variously included addiction, violence, and criminalization. Our participants' experiences are common to those of other adults who are absolutely homeless, according to the current literature. Our participants, however, also told stories of a fateful moment or series of moments that triggered feelings of resiliency, isolation, grief, or fear that underscored their motivation to become housed. Fateful moments changed participants' perceptions and experiences of their homelessness, and thus their sense of their present self and a future self as housed.

During her 20s, Amy's life was characterized by drug use, sex work, mothering, bouts of homelessness, and violence. It was while living with a partner who was a drug dealer that Amy decided to relinquish the care of her children to child welfare services.

So I called and they [Children's Aid Society, hereafter CAS] came and got my two sons. And, ah, and their father was like, ah, he was very resentful that I had done that. And, ah, you know, I didn't see him giving up the selling drugs... I had basically crushed us with my relapses. So now there's no money to pay the rent, you know and, ah, the kids are gone. So there's not really any reason to stay in the apartment... And he can run drugs from anywhere, right. So yeah, we kind of broke up. And without the stability or anybody to account to, I just went off the deep end... you know, I could just see this dragging out, like I'm staying in the shelter... It's an argument with them [CAS] just to get our weekly visits put back together so they see mommy and daddy one time. And I was like, 'no, this is not going to happen.' So I went back out on the streets.

The fateful moment of fracturing intimate ties with her children seemed to set Amy adrift from her identity as mother and more attuned to that of a drug 
using homeless woman. This fateful moment also echoed some of Amy's earlier experiences of family trauma. It was later in her life on the street that a man soliciting for sex attacked her with a knife. This violence became the defining moment from which Amy re-considered her lifestyle:

Three times, he sliced me, three. And like that, ah, really showed me like, you know, either I'm getting older or I'm getting stupider, or I'm just willing to put myself in more risky situations. And I don't even realize that I'm doing it because I'm all about the drugs. You know what I mean? So, if I keep going this way, if I keep going this route, what's going to be the next situation that I get myself into? And I have to stand back... The next situation I may not be able to stand back and go, you know. So, yeah, I think that was a big one for me.

In her early 20s, Jennifer migrated to Toronto from Manitoba with two children and the father of her second child. Her eventual entrance into homelessness was shaped by her drug use and sex work.

When I moved downtown Toronto, it was the first time ever [being homeless] since I was 15. Like I'd lived on the street, but I'd always had... some roof over my head. But when I hit downtown Toronto, it was just different. And so I was living in a hotel... But these people would take over my room and would make it impossible for me to do what I had to do [sex work] to make money to pay it. And I was like five days behind now... because of what I was doing [drug use], I didn't sleep every night anyways. So I just decided I would, you know, when I'm tired, I'll just lay my head down wherever. So I did do that... downtown there, so probably for about eight months I did the sleeping outside and wherever.

Jennifer did not tell a story of a specific fateful moment but rather several that spurred her desire to become housed. She spoke at length of how certain events prompted her growing self-awareness and of her feeling the need to seek out treatment for her addiction especially in order to reconnect with her children. She too had relinquished her children to outside care once on the street: "I always said to myself before I had my children that I would never put my children through what I had to go through growing up, being in that environment. Because it led to where I went." Whereas Amy's story was of constructing an identity as a street person and addict over her identity of mother, Jennifer's story of giving up of her children was in order to preserve her mothering identity. This act was both contradictory and conforming to a core principle of the contemporary ideology of intensive mothering: mothers selflessly care for others more than themselves (Hayes, 1996).

Drug use, crime, trauma, violence, and loss characterized Elijah's life on the street. From 1989 to 2010, Elijah experienced chronic, absolute homelessness and repeated incarceration. Sleeping outdoors led him to be vulnerable to violence: "I've been stabbed a few times. I've been stabbed in my lung, and my abdomen... near my heart with a bottle, cut in my face, stabbed in my eye, stabbed in my kidney." Elijah was also devastated by multiple deaths in his family: "the loss of my son... the loss of my mother. 
Like they both died when I was in jail. My son was murdered." These experiences further alienated him from his family and his sense of self:

I was starting to get distant... from all my family. So now it's just me. So then there was no real emergency to change my life, like there was no real input from nobody to say 'pull yourself up, do this or do that.'... and, ah, the sense of value was lowered, extremely... I wouldn't look at myself and say 'well, I've got to pull up or change the way I'm living or whatever.' I just kept going, going, go to jail, come out of jail, go right back to the block.

The sheer number of Elijah's traumatic experiences can be interpreted as a series of fateful moments. The beginnings of Elijah's transition into becoming housed, however, can be pinpointed down to his epiphany: "I started getting tired of going to jail." Amidst a two decade cycle of homelessness, drug use, crime, and violence, Elijah became tired of Elijah of the self he was on the street.

\section{Perceiving and Creating Social Supports}

Like other researchers of adult homelessness, we find that receipt and exchanges of instrumental and expressive supports, from both informal and formal sources, shaped participants' exits from the street. However, our participants' stories additionally reveal how becoming housed occurs through the intersection of individual, fateful moments with these social supports, especially the creation of fictive kin relations.

Some participants were pulled off the street by kin or fictive kin (informal support), and then further supported through community programs and services, and income assistance (formal support). This pull was effectively felt when it connected to experiences of fateful moments and subsequent individual motivation. Isaac implied his motivation to become housed by his story of social isolation and feeling unloved on the street for the person he was: a man hustling, and being hustled, for money or drugs.

Like on the streets, not having nowhere to go, just realizing like nobody loves me out there, and like everybody just wants one thing from me you know. The money or drugs. And I went home to my mom's [Isabel]... Yeah, like my relationship with my mom is like if, and you're not on no drugs, you can come home, you want to try, you can come home you know.

Isabel's (Isaac's mother) encouragement of Isaac to leave the street also intersected with a series of fateful moments in his life: five close friends died in his last two years on the street and he found out a past girlfriend was pregnant. As he put it: 
I'm going to die out here, the way how my life is going... and then on top of that Amy getting pregnant and, you now, hearing 'oh, it's yours.' So that was an event. And I seen Amy still on the streets. I was kind of like at my mom's. And I just said, 'you know, that doesn't look right.' You know, you running around on the streets, homeless, pregnant. 'If you want to come to my house or whatever, we can work from here. We can start from here.' That's what we did. We started making plans for the baby, yeah.

Isabel's offering of both instrumental and expressive support encouraged Isaac to pursue an identity as a recovering addict - not a drug user - and a father. Isaac became housed by first living with and rebuilding family relations with his mother, partnering with Amy, and then accessing formal social supports including treatment for addiction, social assistance, and subsidized housing.

Amy lived with Isaac in subsidized housing at the time of our interviews with them. Isabel had guardianship of their son since Amy and Isaac were seeking treatment for addiction; she lived part-time the home of Amy and Isaac to support their parenting while sober. We see Amy's experience of extreme violence as a fateful moment that prompted her to entertain leaving the street but also observe that she was pulled off by Isaac and Isabel's offering of instrumental and expressive supports. She explained how this support facilitated her sobriety and her becoming housed:

From Isaac, I just need him for affection that's about it... he's always there for, you know. ... but also she's [Isabel] a role model for me. And she's, I think she's very, very aware of that and she doesn't mind to like, you know, bring over things and show me what I should be cooking. ... and like, you know like ah, tips on financial, like budgeting and stuff like that...

Amy's friend Jennifer also offered crucial expressive support of her becoming housed:

So it's like, you know, when she [Jennifer] started to steer her life in another direction, I didn't even know she was gone. You know, and so we met back up out there [subsidized housing]. I wouldn't say that we were tight or anything [on the street]... because we know each other and it's like a new situation for both our couples... If there's something you guys need, you got it and vice versa.

... [she is] somebody I look to in my sobriety, you know, somebody who I would go to for advice...like just somebody to stay connected in that network...of sobriety, of being clean and sober.

Besides solidifying family ties with Jennifer, Amy's exit from homelessness was further buttressed by a strong relationship she developed with a caseworker at a homeless drop-in centre. The caseworker, according to Amy, is "like a mom and like a police." She counseled Amy on boundary making in order to develop self-esteem and an identity as a sober and housed mother, partner, and friend: "she's just there to make me know that anything 
is possible." Significantly, the caseworker is the godmother of her and Isaac's child.

Other participants' experiences of fateful moments pushed them off the street. They first reached out to formal, community programs and developed strong relationships with front-line caseworkers, and then expanded their informal, family sources of instrumental and expressive support. For example, Jennifer's story of leaving the street is one of personal motivation shaped by not one but a series of fateful moments over time. She sought out support to become housed through a shelter in her community, relying on knowledge she had gained from her earlier experiences of being homeless and becoming housed. She then supplemented her support from community with those she thought of as family: her partner Andrew, as well as Amy and Isaac. Whereas she felt she was simply "passing through" Amy and Isaac's lives when they were all homeless, Jennifer's sobriety and maintenance of a home was supported by family-making with them. In her words, "living in a city you don't have any family right? So, ah, you find, to tend to find family...They're like part of the family... we actually know them from downtown [on the street]. That's where I met them."

For still other participants who experienced criminalization, the interplay between fateful moments and social supports was more complex. Andrew and Elijah's stories illustrate this complexity. Andrew became housed through a fateful moment created by the criminal justice system: he could agree to treatment for addiction under judicial supervision (via drug treatment court) or go to jail. Andrew's commitment to becoming housed and sober was later buttressed by the instrumental and expressive support he received from his treatment program, his partner Jennifer, and friends Isaac and Amy. As part of his recovery, Andrew was also renewing close relationships with his non-custodial children. A rather quiet and reserved man throughout the interview, Andrew was animated when he described his efforts at reembracing his identity as a father: "And now I'm starting to reunite with them... It's going really good... I'm supposed to be seeing her [his daughter] sometime this weekend. I spent last weekend with her..."

Elijah's desire to become housed was pushed by his epiphany about jail time, but similar to Andrew's experience, he was also pulled off the street by the criminal justice system, and specifically, his choice to participate in an out-patient treatment program for addiction in lieu of jail time. As he explained:

I don't want to go out and be dirty again, I don't ever want to be homeless and $\mathrm{CAMH}$ [Centre for Mental Health and Addiction] helps. The program really helps because even though it's not a volunteer thing, it's a requirement because if you don't do the program, you go to jail. So that's a big thing and the main thing is I don't want to be on the streets anymore. 
As well, Elijah's motivation to become housed and stay sober was distinctly tied to a change in self-perception, facilitated by an unexpectedly supportive fictive kin relationship with the peer support worker in his treatment program.

She's like a good friend, she's really close to me. And I go and I see her. Even days that I don't have to...go connect to the group, I still go... because if you want help, you can go, right. So I go because I want the help, I want to get strong right. And I spend time with her. And you know it's inspiring because, you know, she's like my big sister, say. Right, cause we're the same age group but she's ahead of me in recovery so I look up to her... And she sort of looks at me and says 'don't fuck up' you know. And she makes me feel guilty if I do, you know.

Finally, Elijah observed that his transition from the street was further made possible through expressive support received from Amy and Isaac: "When they [Amy and Isaac] heard that I was doing okay, they were so proud of me. Like, they invited me over to their house for dinner... they're my friends." His feelings of isolation in the past were replaced by supportive fictive kin relations, which we perceived to have had a transformative effect on his sense of self.

\section{Discussion}

Our analysis of participants' stories reveals that becoming housed occurs through the interplay of fateful moments with family, community and state support. We see this main finding as offering an opportunity to critically engage with how this interplay unfolds in the neo-liberal social policy context. Specifically, our participants' stories of the processes of becoming housed offer a strong counter-narrative to some neo-liberal assumptions.

On the face of it, the importance of participants' experiences of fateful moments to their becoming housed appears to conform to the neo-liberal principles of individual responsibility, freedom of choice, and selfsufficiency. Through our strategies of narrative analysis, we were able to pinpoint the fateful moment or series of moments that seemed to prompt participants' contemplation about leaving the street (see also Karabanow, 2008) or varying feelings (e.g., fear, isolation). When participants defined fateful moments as suggesting their life off the street was possible, there were distinct elements of personal choice and motivation involved in the subsequent laboring to become housed and often sober. Our participants' stories were layered with evaluations of their agency and responsibility in becoming housed (see also Labov \& Waltezky, 1967).

And yet, through participants' stories, we found that becoming housed could not have been achieved through individual contemplation, motivation, and action alone. Participants' exits from the street were further facilitated by the ways in which fateful moments intersected with informal and formal sources of instrumental and expressive support. To briefly review, some 
participants (e.g., Isaac and Amy) appeared to be pulled out of homelessness by informal (family) supports, and their choice to accept this support intimately tied to their experience of fateful moments. Formal sources of support were initially important to other participants who pushed themselves to become housed in response to a fateful moment or series of them, and were soon supplemented by informal sources of support. For still others, a complex mix of informal and formal - family, community, and state - sources of instrumental and expressive support pulled and pushed participants into housing following opportune moments in their lives.

Our finding of the importance of fictive kin relations also counters what we term "conventional" familialism, an ideology underscoring the neo-liberal policy framework. Conventional familialism rests on the notion that individuals should first and foremost turn to kin for instrumental and expressive support rather than the state; care is to be provided by family first, the state second. The kin imagined, however, are largely relations formed through heteronormative, nuclear family dynamics. Recall that in our study, each of the 15 participants who became housed were members of families by choice, which were an integral component of networks to manage low income. Amy, Isaac, Elijah, Andrew and Jennifer were members of Family 19. Thus, it is particularly noteworthy that many participants in our study sought out instrumental and expressive support from people they defined as family - not simply family determined by blood or marital relations - in the transition to becoming housed. Not all participants who were homeless could just go home or re-unite with kin. Traumatic relations with kin were sometimes the reason participants were on the street. Overcoming homelessness was therefore facilitated by forming intimate partnerships or inventiveness in constructing fictive kin relations. For some participants who became housed and pursued sobriety, the importance of creating and sustaining fictive kin relations could even emerge after supportive relations were developed with community service providers.

This creation of family dovetailed with receipt of other formal supports such as social assistance benefits and access to subsidized housing. However, access to shelter and receipt of income benefits did not mean an escape from income insecurity for our participants; total Ontario Works' incomes did not raise participants above Low Income Cut Offs (Tweddle, Battle \& Torjman, 2013). Community supports for low income families (e.g., food banks, dropin centres) were necessary to participants' meeting the challenges of maintaining housing or sobriety. The meeting of shelter and food needs was further complemented by community treatment for addiction in many cases. Especially when community caseworkers became perceived as family, the distinction between informal and formal sources of support could disappear and ideas about who counts as family significantly blur.

Additionally, all participants told stories of how their renewal or creation of kin and fictive kin relations distinctly influenced their construction of post- 
homeless identities (e.g., of parent, friend, and recovering addict). In their stories of becoming housed, participants were also unravelling and mending tears in the fabric of their self and making sense of their current identities (Linde, 1993). For example, to be a mother for Jennifer meant not mothering her children the way she herself was, and the pursuit of sobriety through family and community supports. Elijah's stories were layered with his deconstruction and reconstruction of who he was, how his character changed on the street, and how his relations of accountability to others while housed mattered to who he wanted to become. Isaac constructed his self as constantly evolving in interactions with others: as moving from the identity of a street person to that of an addict in the past, to being a recovering addict and a father at the time of the interview.

\section{Policy Implications and Recommendations}

As we observed earlier, the neo-liberal policy framework has translated into provincial and municipal responsibility for provisions of affordable housing. Thus far, however, the common political response to homelessness in Toronto continues to be providing and managing emergency shelters at the municipal, city level. Emergency shelters are not a long-term, sustainable plan. They simply move people on and off the street in the short-term. While they provided much needed temporary housing, they do little to correct the limited availability of affordable, permanent housing in the city. As well, the onus of responsibility for finding affordable housing still rests with the individual.

Our research suggests a multi-pronged response to homelessness, involving multi-level governance and coordination of federal, provincial, and municipal policies and programs and community is, at minimum, the strategy we need to imagine. Such a housing strategy, however, cannot be just about increased spending on existing social policies and programs and greater accessibility of affordable housing. Indeed, broader, structural level changes in perspective and interpretation of homelessness are needed. An adequate response to homelessness would begin with a two-fold paradigm shift. First, a concentrated effort that defines housing as a legal (Section 7) and equality (Section 15) right under the Canadian Charter of Rights and Freedoms. Equal access to affordable housing would facilitate social inclusion and social justice (Pomeroy \& Evans, 2008; Rawls, 1971; United Nations, 2006). Second, a realization that people require more than just shelter in order to exit homelessness; they require instrumental and expressive support from multiple sources in order to meet their other health and economic needs. In terms of the latter, we recommend a specific response to homelessness that has the potential to encourage exits from the street. Given our findings, we argue that existing municipal and community programs for the homeless in Toronto and elsewhere, could improve and expand client-centered service by creating 
designated time and space for peer networking and peer mentoring. Peer networking has the potential to recalibrate the power dynamics between service providers and adults who are homeless, in that homeless individuals identify their needs and develop their strategies to meet them through collective exchange. Furthermore, peer mentoring respects homeless individuals' knowledge base and the capacity to exercise a social right of citizenship - the right to be cared for and to care for others. This specific recommendation particularly challenges the neo-liberal ideology that promotes self-reliance and self-care among citizens to resolve market inequalities (Wilson, 2007). Instead, we advocate for an active partnership between the state and citizens that protects and honours citizens' selfdetermination through social relations. In our view, we learn from our participants that responses to homelessness that overlook how becoming housed is a life course transition entangled with personal and structural challenges, and mediated by intersecting fateful moments and available social supports, are simply bound to fail in creating social inclusion and housing justice.

\section{Conclusion}

The purpose of this paper was to explore the processes by which absolute homeless adults become housed in the midst of multiple barriers, including their social location within a neo-liberal social policy context. We used strategies of narrative analysis to explore these processes. Our analytic strategies allowed us to attend to the events and interactions linked to becoming housed, and the changes of self that occur in the midst of them. In doing so, we closely followed Amy, Isaac, Elijah, Jennifer, and Andrew's stories to find that it is the interplay of fateful moments and social support that culminate in becoming housed. Though ours is cross-sectional research focused on a small sample of stories of adults (and so not generalizable), our findings contribute to our understanding of the processes of becoming housed. Our study also encourages us to seriously consider the difficulties in responding to homelessness in a neo-liberal social policy context. To quote Larner (2000, p. 21): "in acknowledging the complexity of neo-liberalism we stand a better chance of identifying possibility to advance social justice aims in a new context."

\section{Acknowledgements}

We are grateful for the time and knowledge participants shared with us. We are also grateful to the anonymous reviewers for their comments, which improved the quality of this paper. Finally, we thank Katherine Bischoping 
and Benjamin Christensen for their supportive reads of an earlier draft of this paper. The study referred to in this paper was funded by the Social Sciences and Humanities Research Council (Grant no. 410- 410-2007-1071). It was approved by the Human Participants Review Sub-Committee at York University.

\section{References}

Allen, K. R., \& Pickett, R. S. (1987). Forgotten streams in the family life course: Utilization of qualitative retrospective interviews in the analysis of lifelong single women's family careers. Journal of Marriage and the Family, 49(3), 517-526.

Adams, G. R., \& Marshal, S. K. (1996). A developmental social psychology of identity: Understanding the person-in-context. Journal of Adolescence, 19(5), 429-442.

Ahmed, A. (2013). Structural narrative analysis: Understanding experiences of lifestyle migration through two plot typologies. Qualitative Inquiry, 19(30), 232-242.

Anderson, J. T. \& Collins, D. (2014). Prevalence and causes of urban homelessness among Indigenous peoples: A three-country scoping review. Housing Studies, 29(7), 959-976.

Armstrong, P., \& Armstrong, H. (2010). Wasting away: The undermining of Canadian health care. Toronto: Oxford University Press.

Belanger, Y. D., Awosoga, O., \& Head, G. W. (2013). Homelessness, urban Aboriginal people, and the need for a national enumeration. Aboriginal Policy Studies, 2(2), 4-33.

Belcher, J. R., \& DeForge, B. R. (2012). Social stigma and homelessness: The limits of social change. Journal of Human Behavior in the Social Environment, 22(8), 929-946.

Benjamin, W. (1936/1968). The storyteller: reflections on the works of Nikolai Leskov. In H. Arendt (Ed.), Illuminations: Essays and reflections (pp. 83-110). New York: HarcourtBrace Jovanovich.

Berger, R. J. (2008). Agency, structure, and the transition to disability: A case study with implications for life history research. The Sociological Quarterly, 49(2), 309-333.

Bischoping, K., \& Gazso, A. (2016). Analyzing talk in the social sciences: Conversation, discourse, and narrative strategies. London: Sage.

Bourgois, P., \& Schonberg, J. (2009). Righteous dopefiend. Berkeley: University of California Press.

Briggs, C. (1986). Learning how to ask: A sociolinguistic appraisal of the role of the interview in social science research. New York: Cambridge University Press.

Broadbent Institute. (2014). Haves and have nots: Deep and persistent wealth inequality in Canada. Retrieved from www.broadbentinstitute.ca/income inequality

Brodie, J. (2007). Reforming social justice in neo-liberal times. Studies in Social Justice, 1(2), 93-107.

Bulos, M., \& Chaker, W. (1995). Sustaining a sense of home and personal identity. In D. N. Benjamin \& D. Stea (Eds.), The home: Words, interpretations, meanings, and environments (pp. 227-239). Aldershot, UK: Avebury Press.

Chamberlain, C., \& Johnson, G. (2013). Pathways into adult homelessness. Journal of Sociology, 49(1), 60-77.

City of Toronto. (2013). 2013 Street Needs Assessment Results. Toronto: City of Toronto. Retrieved from www1.toronto.ca/wps/portal/contentonly?vgnextoid=c022ecbc9c916410VgnVCM1000007 1d60f89RCRD

Coates, J., \& McKenzie-Mohr, S. (2010). Out of the frying pan, into the fire: Trauma in the lives of homeless youth prior to and during homelessness. Journal of Sociology and Social Welfare, 37(4), 65-96.

Cooke, M. \& Gazso, A. (2009). Taking a life course perspective on social assistance use in Canada: A different approach” Canadian Journal of Sociology, 34(2), 349-372.

Crouch, M., \& McKenzie, H. (2006). The logic of small samples in interview-based 
qualitative research. Social Science Information, 45(4), 483-499.

Daiski, I., Halifax, N., Davis, V., Mitchell, G. J., \& Lyn, A. (2012). Homelessness in the suburbs: Engulfment in the grotto of poverty. Studies in Social Justice, 6(1), 103-123.

Dolson, M. S. (2015). By sleight of neoliberal logics: Street youth, workfare, and the everyday tactics of survival in London, Ontario, Canada. City \& Society, 27(2), 116-135.

Dordick, G. A. (1997). Something left to lose: Personal relations and survival among New York's homeless. New York: Temple University Press.

Duneier, M. (1999). Sidewalk. New York: Farrar, Straus \& Giroux.

Eberle, M. P. (2001). Homelessness - Causes \& effects (Vol. 4): Background Report - a profile and policy review of homelessness in the provinces of Ontario, Quebec and Alberta. Vancouver: British Columbia Ministry of Social Development \& Economic Security, \& BC Housing Management Commission.

Elder, G. H. Jr. (1994). Time, human agency, and social change: Perspectives on the life course. Social Psychology Quarterly, 57(1), 4-15.

Elder, G. H. Jr. (1998). The life course as developmental theory. Child Development, 69(1), 1-12.

Forchuk, C., Ward-Griffin, C., Csiernik, R., \& Turner, K. (2006). Surviving the tornado of mental illness: Psychiatric survivors' experiences of getting, losing, and keeping housing. Psychiatric Services, 57(4), 558-562.

Frankish, C. J., Hwang. S. W., \& Quantz, D. (2005). Homelessness and health in Canada: Research lessons and priorities. Canadian Journal of Public Health, 96(2), S23-S29.

Gaetz, S. (2010). The struggle to end homelessness in Canada: How we created the crisis, and how we can end it. Open Health Services and Policy Journal, 3, 21-26.

Gaetz, S. (2013). The criminalization of homelessness: A Canadian perspective. European Journal of Homelessness, 7(2), 357-362.

Gaetz, S., Richter, T., Donaldson, J., \& Gulliver, T. (2013). The state of homelessness in Canada 2013 (Homeless Hub Paper 4). Toronto: Canadian Homelessness Research Network Press. Retrieved from: http://www.homelesshub.ca/SOHC2013

Gasker, J. A. (1999). I never told anyone this before: Managing the initial disclosure of sexual abuse re-collections. London: The Haworth Maltreatment and Trauma Press.

Gazso, A. (2012). Moral codes of mothering and the introduction of welfare-to-work in Ontario. Canadian Review of Sociology, 49(1), 26-49.

Gazso, A., \& McDaniel, S. (2015). Families by choice and the management of low income through social supports. Journal of Family Issues, 36(3), 371-395.

Giddens, A. (1991). Modernity and self-identity: Self and society in the late modern age. Cambridge: Polity Press.

Goodey, J. (2000). Biographical lessons for criminology. Theoretical Criminology, 4(4), 473498.

Grinman, M. N., Chiu, S., Redelmeier, D.A., Levinson, W., Kiss, A., Tolomiczenko, G., \& Hwang, S.W. (2010). Drug problems among homeless individuals in Toronto, Canada: Prevalence, drugs of choice, and relation to health status. BMC Public Health, 10, 94.

Harvey, D. (2007). A brief history of neoliberalism. New York: Oxford.

Hayes, S. (1996). The cultural constructions of motherhood. New Haven, CT: Yale University Press.

Howard, C. (2007). Introducing individualization. In C. Howard (Ed.), Contesting individualization: Debates about contemporary personhood (pp. 1-24). New York: Palgrave MacMillan.

Hulchanski, J. D. (2009, February). Homelessness in Canada: Past, present and future. Keynote address presented at the Growing home: Housing \& homelessness in Canada conference, Calgary AB. Retrieved from: http://tdrc.net/uploads/file/2009_hulchanski.pdf

Irwin, J., LaGory, M. E., Ritchey, F. J., \& Fitzpatrick, K. M. (2008). Social assets and mental distress among the homeless: Exploring the roles of social support and other forms of social capital on depression. Social Science and Medicine, 67(12), 1935-1943.

Jackson, M. (2002). The politics of storytelling: Violence, transgression, and intersubjectivity. Copenhagen: Museum Tusculanum Press. 
Karabanow, J. (2008). Getting off the street. American Behavioral Scientist, 51(6), 772-788. Karabanow, J., Hughes, J., Ticknor, J., Kidd, S., \& Patterson, D. (2010). The economics of being young and poor: How homeless youth survive in neo-liberal times. Journal of Sociology and Social Welfare, 37(4), 39-64.

Klodawsky, F., Aubry, T., Nemiroff, R., Bonetta, C., \& Willis, A. (2007). What happens over time: Researching homelessness longitudinally. Canadian Journal of Urban Research, 16(1), 93-111.

Kroger, J. (2000). Identity development: Adolescence through adulthood. Thousand Oaks, CA: Sage Publications.

Labov, W., \& Waletzky, J. (1967). Narrative analysis. In J. Helm (Ed.), Essays on the verbal and visual arts (pp. 12-44). Seattle: University of Washington Press.

Larner, W. (2008). Neoliberalism: Policy, ideology, governmentality. Studies in Political Economy, 63, 5-25.

Lewchuk, S. (2013, February 13). Affordable housing in Canada: Federal investments in the decline. Citizens for Public Justice, Ottawa, ON. Retrieved from: www.cpj.ca/content/affordable-housing-canada-federal-investments-decline

Linde, C. (1993). Life stories: The creation of coherence. Cary, NC: Oxford University Press.

MacKnee, C. M., \& Mervyn, J. ( 2002). Critical incidents that facilitate homeless people's transition off the streets. Journal of Social Distress \& the Homeless, 11(4), 293-306.

Main, T. (1998). How to think about homelessness: Balancing structural and individual causes. Journal of Social Distress \& the Homeless, 7(1), 41-54.

Mallett, S., Rosenthal, D., \& Keys, D. (2005). Young people, drug use and family conflict: Pathways into homelessness. Journal of Adolescence, 28(2), 185-199.

McDaniel, S., Gazso, A., \& Duncan, K. (2016). Relative prospects of children as they age: Canadians and Americans in mid-life in the great recession frame future generations. Journal of Aging Studies, 37, 69-80.

McDonald, L. (2011). Examining evictions through a life-course lens. Canadian Journal of Public Policy, 37(S1), S115-S133.

McKeen, W., \& Porter, A. (2003). Politics and transformation: Welfare state restructuring in Canada. In W. Clement \& L. Vosko (Eds.), Changing Canada: Political economy as transformation (pp. 109-134). Montreal: McGill-Queen's University Press.

Mead, G. H. (1934/1984). Mind self and society from the standpoint of a social behaviorist. Chicago, IL: University of Chicago Press.

Mishler, E. G. (1991). Research interviewing: Context and narrative. Cambridge: Harvard University Press.

Monsebraaten, L. (2016, May 25). Ontario's affordable housing wait list grows. The Toronto Star. Retrieved from www.thestar.com/news/gta/2016/05/25/ontarios-affordable-housingwait-list-grows.html

Mykelbust, J. O., \& Solvang, B. (2005). Young mothers with special education needs. Young: Nordic Journal of Youth Research, 13(1), 73-87.

Nemiroff, R., Aubry, T., \& Klodawsky, F. (2010). Factors contributing to becoming housed for women who have experienced homelessness. Canadian Journal of Urban Research, 19(2), 23-45.

Niles, C. (2013). Examining the deinstitutionalization movement in North America. Health Tomorrow, 1(1), 54-83.

O'Gady, B., Gaetz, S., \& Buccieri, K. (2013). Tickets....and more tickets: A case study of the enforcement of the Ontario Safe Streets Act. Canadian Public Policy, 39(4), 541-558.

Ontario Ministry of Municipal Affairs \& Housing. (2014). Long-term funding for affordable housing. Retrieved from: http://www.mah.gov.on.ca/Page10444.aspx

Organization for Economic Co-operation and Development. (2008). Growing unequal? Income distribution and poverty in OECD Countries. Retrieved from www.oecd.org/els/soc/growingunequalincomedistributionandpovertyinoecdcountries.htm

Peck, J., \& Tickell, A. (2002). Neoliberalizing Space. Antipode, 34(3), 380-404.

Persaud, S., McIntyre, L., \& Milaney, K. (2010). Working homeless men in Calgary, Canada: Hegemony and identity. Human Organization, 69(4), 343-351. 
Pomeroy, S. \& Evans, L. (2008). Housing as a mechanism in poverty reduction strategies: A brief review of international experience and implications for Ontario. Toronto: Ontario Non-Profit Housing Association.

Prus, S. G. (2004). A life course perspective on the relationship between socio-economic status and health: Testing the divergence hypothesis. Canadian Journal on Aging, 23(S1), S145S153.

Raskin, P. M. (2006). Women, work, and family: Three studies of roles and identity among working mothers. American Behavioral Scientist, 49(10), 1354-1381.

Rawls, J. (1971). A theory of justice. Cambridge, MA: Belknap Press.

Rice, J. J., \& Prince, M. J. (2013). Changing politics of Canadian social policy $\left(2^{\text {nd }}\right.$ ed.). Toronto: University of Toronto Press.

Rokach, A. (2004). The lonely and homeless: Causes and consequences. Social Indicators Research 69(1), 37-50.

Rokach, A. (2005). Private lives in public places: Loneliness of the homeless. Social Indicators Research, 72(1), 99-114.

Shier, M., Jones, M., \& Graham, J. (2010). Perspectives of employed people experiencing homelessness of self and being homeless: Challenging socially constructed perceptions and stereotypes. Journal of Sociology \& Social Welfare, 37(4), 13-37.

Snow, D., \& Anderson, L. (1993). Down on their luck: A study of homeless street people. Berkeley, CA: University of California Press.

Stablein, T. (2011). Helping friends and the homeless milieu: Social capital and the utility of street peers. Journal of Contemporary Ethnography, 40(3), 290-317.

Sterk-Elifson, C., \& Elifson, K. W. (1992). Someone to count on: Homeless, male drug users and their friendship relations. Urban Anthropology \& Studies of Cultural Systems \& World Economic Development, 21(3), 235-251.

Strauss, A. L., \& Corbin, J. M. (1998). Basics of qualitative research: Grounded theory procedures and techniques. Thousand Oaks, CA: Sage Publications.

Thompson, S. J., Bender, K., Windsor, L., Cook, M. S., \& Williams, T. (2010). Homeless youth: Characteristics, contributing factors, and service options. Journal of Human Behaviour in the Social Environment, 20(2), 193-217.

Toro, P. A., \& Oko-Riebau, M. (2015). Social support and stress among homeless adults in southern Poland. Journal of Community Psychology, 43(4), 430-446.

Toro, P. A., Tulloch, E., \& Ouellette, N. (2008). Stress, social support, and outcomes in two probability samples of homeless adults. Journal of Community Psychology, 36(4), 483-498.

Tutty, L. M., Ogden, C., Giurgiu, B., \& Weaver-Dunlop, G. (2013). I built my house of hope: Abused women and pathways into homelessness. Violence Against Women, 19(12), 14981517.

Tweddle, A., Battle, K., Torjman, S. (2013). Canada social report: Welfare in Canada, 2012. Ottawa: Caledon Institute for Social Policy. Retrieved from www.canadasocialreport.ca/

Twigger-Ross, C. L., \& Uzzell, D. L. (1996). Place and identity process. Journal of Environmental Psychology, 16, 205-220.

United Nations. (2006). Social Justice in an open world: The role of the United Nations. New York: United Nations. Retrieved from www.un.org/development/desa/socialperspectiveondevelopment/2015/08/20/social-justicein-an-open-world-the-role-of-the-united-nations/

Wilks, N., Hiscock, E., Joseph, M., Lemin, R., \& Stafford, M. (2008). Exit this way: young people transitioning out of homelessness. Social Alternatives, 27(1), 65-70.

Wilson, B. M. (2007). Social justice and neoliberal discourse. Southeastern Geography, 47(1), 97-100.

Zlotnick, C., Tam, T., \& Robertson, M. J. (2003). Disaffiliation, substance use, and exiting homelessness. Substance Use \& Misuse, 38(6), 577-599. 